\title{
If Humans Can Change for the Better, We Can Change the World
}

\author{
J. T. Trevors
}

Published online: 5 October 2010

(C) Springer Science+Business Media B.V. 2010

If humans can change for the betterment of humanity and our shared biosphere, we can change the world, so it is sustainable with minimal pollution, not over populated, hunger and poverty are eliminated, conflicts, wars, discrimination and intolerance ended, and humanity moves forward with positive, progressive, democratic change. The only means to accomplish this global task is through enlightened, scholarly education free from religion, trivia, indoctrination, and mind control. This may appear to be an impossible task, but if humans reflect upon this, the alternative is the crisis-upon-crisis humanity is confronted with today. History will judge this time period as many humans being on the wrong side of history consumed with greed, selfishness, war, conflicts, discrimination, terrorism, and contributing absolutely nothing to humanity and our common biosphere.

The correct education system can liberate humans from discrimination, indoctrination, false beliefs, consumer-driven and selfish activities, consumption and waste, and replace these with humanitarian actions, conservation, and a commitment to worldwide democracies. It is an immense task to evolve a

J. T. Trevors $(\bowtie)$

School of Environmental Sciences, University of Guelph, Guelph, Ontario N1G 2W1, Canada

e-mail: jtrevors@uoguelph.ca democracy in a country consumed by religious indoctrination and oppressive dictatorships with every human right violation. It is difficult for other democratic countries to assist the citizens of oppressed countries to establish and evolve their democracies. Sovereign countries are sovereign countries. However, establishing democracies provides the opportunity for the democracy to evolve and policies to be implemented that citizens have participated in through democratic activities. One can argue there are no true democracies where the rights of all individuals are always placed before the state. Every democracy has some degree of fascist activity where the state is placed ahead of the rights' of all individuals. This simply means democracies have not evolved to true democracies and still have an immense amount of democratic evolution ahead of them. This will be necessary for humans to agree that overpopulation, global climate change, and conflicts are not our future.

There is no simple formula for how to design and implement a liberal, scholarly, enlightened education system in any country, including the so-called democracies. I suspect there are those who do know how to do this. I do hope they join forces, promote universal education, and are successful. I do know that in a complex, globally polluted world with several billion too many humans and immense human suffering and death, that education and democratic states are an immense part of the solution. There is no 
future for humanity without excellent education systems in real democracies.

The role of the modern university is to evolve modern, stable, democratic countries capable of governance and international cooperation. This will assist in protecting human rights amidst the current global crises of uncontrolled human population growth, global climate change, failed states, conflicts, discrimination, pandemics, hunger, decreasing food reserves, poverty, resource depletion, loss of biodiversity, inadequate transportation, and inadequate public health and communication services. Universities are uniquely positioned to from national and global networks for teaching/research and intellectual expansion, all for the good of humanity and somewhat free from political interference and corruption in many countries. Universities will need to strive even more to critically evaluate knowledge, challenge knowledge, and extend intellectual boundaries locally, nationally, and globally.

Only a learning society can engineer and evolve a modern democratic country. To meet this objective, countries must have an excellent educational system at all levels. The people who administer universities cannot buy, spend, always increase fees, nor talk their way out the lack of real scholarship and commitments to evolving democracies. Universities must produce scholars not simply graduates and more consumers.
Scholars must know how to put knowledge to work for humanity. Students must be placed in an environment where they are able to learn, fail and still succeed, and fail and not always succeed. When some fail others must succeed to move humanity forward. Students must recognize when to reject incorrect advice and knowledge. Instructors may be clever but lack a strategic vision for humanity. The world needs instructors who can accomplish all scholarly tasks.

The objective is not to be successful at something that is meaningless. All learning humans must expose their ideas and thoughts to informed peers for constructive criticism. It is difficult for students to succeed unless they are learning with successful instructors. Instructors who are not critical thinkers will not be able to teach critical thinking that is engaged, disciplined, interconnected subject areas, defensible, self-directed, capable of accessing relevant knowledge and information and arriving at well-reasoned and correct policies, solutions, and conclusions.

Universities pride themselves in being innovative, but innovation must go beyond the immediate university setting. Universities must be better at navigating the routes from research and intellectual concepts to the betterment of humanity. The points where universities engage with societies and humanity must be better defined and implemented so global crises can be solved. 